\title{
CHRZEST A ZBAWIENIE CZLOWIEKA: WAŻNOŚĆ I KONIECZNOŚĆ CHRZTU W ŚWIETLE POLEMIKI AUGUSTYNA $Z$ DONATYSTAMI
}

Jeden z pierwszych znaczących sporów teologicznych w Kościele dotyczył chrztu, jego ważności i powtarzalności ${ }^{1}$. Głośna kontrowersja, jaka zaistniała między biskupem Cyprianem z Kartaginy a biskupem Stefanem z Rzymu, ujawniła znaczące różnice istniejące w tej materii wśród teologów i duszpasterzy² ${ }^{2}$. Biskup Kartaginy nie uznawał chrztu udzielonego przez heretyków i opowiadał się za ponownym udzielaniem chrztu tym, którzy ochrzczeni poza Kościołem katolickim chcieli do niego przystąpić. Autorytet biskupa Cypriana zaważył na tym, że stanowisko, jakie zajął w tej sprawie on i synod biskupów, któremu przewodniczył, weszły do praktyki Kościoła w Afryce. Nie było to jednak stanowisko podzielane przez cały Kościól ${ }^{3}$. Już synod rzymski (255/256) tę praktykę odrzucił, na początku zaś IV wieku, decyzję tego synodu potwierdzono na innych synodach łacińskich i to stanowisko przyjęło się powszechnie w Kościele łacińskim $^{4}$. Spór o zasadność tego stanowiska nabrał dynamiki w związku z wybuchem schizmy donacjańskiej. Donatyści, powołując się na autorytet Cypriana, nie uznawali chrztu udzielonego w Kościele katolickim ${ }^{5}$. Odparcia tych pretensji oraz uzasadnienia stanowiska Kościoła łacińskiego podjął się Augustyn z Hippony, a swój pogląd wyraził najpełniej w traktacie $O$ chrzcie ${ }^{6}$.

Rozprawa Augustyna była w pierwszym rzędzie polemiką z donatystami, ale pośrednio ze stanowiskiem Cypriana. Stanowisko zaprezentowane przez autora traktatu zyskało uznanie w Kościele i w dużej mierze ukierunkowało sposób

${ }^{1}$ Szerzej por. K. Baus, Handbuch der Kirchengeschichte, hrsg. H. Jedin, Bd. I, Freiburg Wien 1965, 373-386.

${ }^{2}$ Szerzej por. R. J. De Simone, Battesimo. Controversia, DPAC I 507.

${ }^{3}$ Chociaż stanowisko Kościoła afrykańskiego podzielały niektóre inne Kościoły lokalne, por. H. Pietras, Dionizy Aleksandryjski wobec sporu o wazność chrztu heretyków, RTK 36 (1989) z. 4, 103-118.

${ }^{4}$ Por. Concilium Arelatense (314) can. 9 i 28, SCL 1, 72 i 74.

${ }^{5}$ Szerzej por. W.H.C. Frend, Donatismo, DPAC I 1014-1025; A. Żurek, Wstęp, w: Augustyn z Hippony, O chrzcie, tłum. A. Żurek, ŹMT 38, Kraków 2006, 8-12.

6 Augustinus, De baptismo contra Donatistas, ed. M. Petschening, CSEL 51, Vindobonae 1908, 145-375, thum. A. Żurek, jw., ŹMT 38. 
myślenia o tajemnicy chrztu. Z tego choćby powodu warto je przypomnieć. Interesujący jest też sposób argumentowania i teologicznego wnioskowania.

1. Chrzest - sakramentem Chrystusa. Augustyn od samego początku w pełni popierał zasadność praktyki stosowanej w jego czasach w Kościele katolickim. Opowiadał się za ważnością chrztu udzielonego w schizmie, ale nie wystarczało mu odwoływanie się tylko do „starodawnego zwyczaju” i orzeczeń synodalnych, które nie przytaczały żadnych teologicznych uzasadnień. Takich argumentów on sam potrzebował. Dyskusje z donatystami, które w jego czasach na nowo nabrały dynamiki, stanowiły dodatkowy bodziec do intensyfikowania poszukiwań racji teologicznych. Znaleźć je można było na drodze systematycznych badań.

Punktem wyjścia w rozumowaniu Augustyna była refleksja nad samym sakramentem chrztu i nad jego tajemnicą. Powołując się na słowa Jana Chrzciciela, wskazującego na Chrystusa: „On jest Tym, który chrzci Duchem Świętym" (J 1, 3), stanowczo podkreślał, że chrzest:

„niezależnie od tego, przez jakiego szafarza zostanie udzielony, jest zawsze chrztem Tego, o którym zostało powiedziane: «to jest Ten, który chrzci»"”.

Jest to zatem „,chrzest Chrystusa” (baptismum Christi) ${ }^{8}$. Można się w zasadzie tylko domyślać, że w tym określeniu zawiera się przekonanie o ustanowieniu sakramentu chrztu przez Chrystusa, choć wprost Augustyn o tym nie mówił ani też do tego nie przywiązywał wagi. Mówiąc o „chrzcie Chrystusa” miał na myśli przede wszystkim aktualne działanie Chrystusa w sakramencie. W efekcie, polemizując zwłaszcza z donatystami, mógł powiedzieć:

„, chrzest udzielony przez człowieka godnego wzgardy, tyle samo znaczy, co chrzest udzielony przez apostoła. Wiadomo przecież, że nie jest on własnością ani jednego, ani drugiego, ale Chrystusa"

By chrzest został rzeczywiście udzielony, musi być spełniony tylko jeden warunek: ma być udzielony zgodnie z poleceniem Chrystusa i przy użyciu „,ewangelicznej formuły", czyli w imię Trójcy Świętej ${ }^{10}$. Augustyn był tak przekonany o tym, że chrzest nie zależy w ogóle od człowieka, że nie wahał się uznać za ważny chrzest udzielony dla kpiny lub żartu, byle tylko dokonało się to z użyciem ,ewangelicznej formuły”, a chrzest został „przyjęty bez obłudy oraz z odrobiną wiary"11.

7 Tamże V 12, 14, CSEL 51, 275, ŹMT 38, 142.

8 Określenia „,baptismum Christi” używa Augustyn bardzo często, por. De baptismo I 3, 4; I 4,

5; I 5, 6; I 5, 7; I 10, 13, itp.

9 De baptismo V 13, 15, CSEL 51, 275-276, ŹMT 38, 143.

${ }^{10}$ Por. tamże III 15, 20, CSEL 51, 211, ŹMT 38, 88.

11 Tamże VII 53, 102, CSEL 51, 374, ŹMT 38, 227 
Zdanie św. Pawła o ,jednym chrzcie” (Ef 4, 5), z którym zgadzali się także oponenci, Augustyn interpretował w sposób radykalny. Uważał, że chrzest raz dobrze udzielony, niezależnie gdzie i przez kogo, pozostaje „święty” i niepowtarzalny $^{12}$. Ze swej bowiem natury jest to „sakrament sam z siebie święty”,13, a jego „świętość” nie może przez nikogo i w żaden sposób zostać zanieczyszczona: ani przez brak właściwej dyspozycji szafarza, ani przez nieprzygotowanego na ten akt przyjmującego ${ }^{14}$. Skoro jest „chrztem Chrystusa” to pozostaje „święty” wszędzie: u katolików, heretyków, schizmatyków ${ }^{15}$.

Trwałość i nieodwołalność sakramentu chrztu zaznacza się przez to w ochrzczonym, że nadaje mu coś w rodzaju nieusuwalnego znaku. W terminologii Augustyna jest to dominicus character, na trwałe znamionujący ochrzczonego $^{16}$. Z tej też racji sakramentu tego nigdy nie można utracić, niezależnie od dalszych losów ochrzczonego. Biblijnym dowodem nieutracalności chrztu był Szymon Mag (Dz 8, 18-24), który ,posiadał sakrament chrztu”, a „mimo to nie wszedł do królestwa niebieskiego"17. Samego chrztu jednak nie utracił, czego nikt ani wtedy, ani później nie kwestionował. Podobnie było w znanej Augustynowi poapostolskiej tradycji Kościoła. Nawet Cyprian, tak pryncypialny w kwestiach chrztu ustalił:

„że każdy ochrzczony w Kościele, [a potem] powracający z herezji do Kościoła, zostanie przyjęty nie przez [ponowny] chrzest, ale przez pokutę"18.

Uznawał tym samym, że również poza Kościołem nie traci się chrztu raz ważnie udzielonego ${ }^{19}$. Nawet największe grzechy, a do takich zaliczano apostazję, nie niweczą samego chrztu. Wnioski Augustyna brzmiały radykalnie. Według niego:

„Może się zdarzyć, że ktoś byłby gorszy niż poganin, a mimo to sakrament Chrystusa w nim nie tylko jest, ale nawet nie jest on gorszy niż [ten sam sakrament] w człowieku świętym i sprawiedliwym. Na ile to zależy od człowieka, to ten sakrament nie został w nim ustrzeżony, ale nawet przez tego człowieka, w sposób zamierzony i świadomy, zniszczony. Jednak o ile chodzi o sam sakrament, to on przetrwał pełny i niezniszczony w swoim gwałcicielu i wzgardzicielu"20.

12 Por. tamże IV 12, 18, CSEL 51, 244, ŹMT 38, 116.

13 Tamże IV 14, 21, CSEL 51, 246, ŹMT 38, 118.

14 Por. tamże III 10, 15, CSEL 51, 205, ŹMT 38, 83.

15 Por. tamże I 19, 29, CSEL 51, 173, ŹMT 38, 56. Jak łatwo zauważyć, Augustyn mówiąc o „świętości” chrztu wyrażał w sposób opisowy prawdę o tym, o czym późniejsza teologia będzie mówić operując terminem ,ważność” chrztu.

16 Por. tamże VI 1, 1, CSEL 51, 298, ŹMT 38, 164. Co Augustyn rozumiał pod pojęciem „character” stanowi przedmiot dyskusji. Szerzej por. E. Cataneo, Introduzione, w: Agostino d'Ippona, Sette libri sul battesimo. In dialogo con i donatisti, Palermo 2004, 49.

17 Augustinus, De baptismo VI 12(18), 19, CSEL 51, 310, ŹMT 38, 173.

18 Tamże III 11, 16, CSEL 51, 206, ŹMT 38, 84.

19 Por. Cyprianus, Epistola 71, 2.

20 Augustinus, De baptismo VI 44, 86, CSEL 51, 339, ŹMT 38, 197. 
2. Chrzest Kościoła. Cyprian z Kartaginy konieczność udzielania chrztu ludziom ochrzczonym w schizmach uzasadniał tym, że nakaz udzielania chrztu i władzę odpuszczania grzechów otrzymał od Chrystusa Kościół w osobach Apostołów. Biskup Kartaginy z całym przekonaniem podkreślał: „Tylko Kościół posiada całą władzę swego Oblubieńca i Pana"21. Powoływał się przy tym na naukę św. Pawła, zgodnie z którą: ,jeden jest Pan, jedna wiara i jeden chrzest" (Ef 4,5) i tym samym może być tylko jeden Kościól ${ }^{22}$. Kto znajduje się poza Kościołem, znajduje się poza wspólnotą z Chrystusem. Tym samym pozbawia się dóbr udzielonych Kościołów, wśród nich także tego, który jest warunkiem zbawienia, bo: „poza Kościołem nie ma zbawienia”23. Ten widzialny Kościół reprezentują tylko ustanowieni przez niego szafarze, co w praktyce oznaczało przede wszystkim biskupów. Stanowisko reprezentowane przez Cypriana wyrażało się w zdaniu:

„Władza odpuszczania grzechów została dana apostołom i Kościołom, które oni posłani przez Chrystusa, założyli oraz biskupom, którzy otrzymują święcenia, aby stać się następcami apostołów"24.

Ostatecznie więc, tylko chrzest udzielony przez szafarzy Kościoła posiadał moc nadaną mu przez Chrystusa. Poza Kościołem „nikt nie może zostać ochrzczony" 25 .

Tropem myśli Cypriana podążyli w IV wieku donatyści. Do przedstawionego co dopiero rozumowania dołożyli jedną, istotną jednak modyfikację. Według nich świętość chrztu domaga się, by udzielali go święci - w ich mniemaniu i według ich kryteriów - szafarze. Pomijając już nawet dyskusję na temat wiarygodnego wskazania „Kościoła świętych” i niekonsekwencje, jakie w tym względzie demonstrowali donatyści, najważniejszą kwestią było uzależnienie ważności chrztu od świętości szafarza ${ }^{26}$. Argumenty biblijne za takim powiązaniem trudno było znaleźć i tych nawet donatyści nie szukali. Wystarczyło im, jak się wydaje, dla uzasadnienia swego stanowiska odwołanie się do praktyki Cypriana, który polecał ponownie chrzcić przychodzących z herezji i tam ochrzczonych oraz przekonanie o prawdziwości i świętości swojego Kościoła. Nie potrzebowali i nie zaprzątali sobie głowy szukaniem teologicz-

${ }^{21}$ Cyprianus, Epistola 73, 11, 1, CCL 3C, 541, thum. W. Szołdrski, PSP 1, 264.

22 Por. Cyprianus, Epistola 74, 11.

23 Tamze 73, 21, 2, CCL 3C, 555: „,salus extra Ecclesiam non est”.

24 Tamze 75, 16, 1, CCL 3C, 596, PSP 1, 291.

25 Tamże 70, 1, 2, CCL 3C, 503: ,pro certo tenentes neminem baptizari foris extra Ecclesiam posse".

${ }^{26}$ W praktyce, donatyści za świętego uważali tylko aktualnego członka swej wspólnoty. Niekonsekwencje w swym postępowaniu okazali przy okazji sporów i rozłamów, do jakich wśród nich doszło pod koniec IV wieku, spowodowanych przez Maksymianina. Przyjmowali później, bez powtarzania chrztu, nie tylko wcześniej usuniętych swoich członków, ale też ochrzczonych przez maksymianistów, szerzej por. Augustinus, De baptismo I 5, 7, CSEL 51, 152-153, ŹMT 38, 38. 
nych argumentów, uzasadniających konieczność udzielania chrztu przez świętego szafarza.

Augustyn nie negował ścisłego związku chrztu z Kościołem. Jednak zarówno doświadczenie duszpasterskie, jak też rozumowanie teologiczne, nie pozwały mu na takie samo spojrzenie, jakie miał Cyprian, a przede wszystkim donatyści. Argumentację Cypriana i jego zwolenników zakwestionował powołując się na inny tekst św. Pawła. Apostoł Narodów w jednym z listów pisał o takich, którzy pozornie są w Kościele, choć faktycznie są poza nim. Są to ci, którzy według słów św. Pawła: „nie posiądą królestwa Bożego” (1Kor 6, 10; Ef 6, 5). Tymczasem, zarówno sam św. Paweł, jak też Cyprian poświadczają, że tacy znajdują się nawet wśród episkopatu ${ }^{27}$. Ludzie będący „,chciwcami, rozbójnikami, lichwiarzami, zawistnikami, złośliwcami i im podobnymi, nie należą do świętego Kościoła Bożego, chociaż wydają się w nim być"28. Generalnie za prawdziwe należy uznać zdanie:

„Ten, komu brakuje miłości i krocząc zatraceńczą drogą najgorszych obyczajów, wydaje się być w Kościele, choć jest poza nim”29.

Odnosi się to zarówno do szafarzy, jak też do przyjmujących chrzest. Gdyby zatem ważność chrztu zależała od rzeczywistej więzi z Kościołem, to niegodni biskupi będący szafarzami chrztu, udzielaliby go nieważnie ${ }^{30}$. Tymczasem, mimo stwierdzenia takich faktów, nikt nie kwestionuje ważności chrztu udzielanego przez takich biskupów, ani też nie proponuje jego powtórzenia. Sama praktyka dowodzi zatem, że Kościół od samego początku nie uzależniał ważności chrztu od szafarza.

Jeszcze łatwiej można było zakwestionować argumentację donatystów. Już z czasów poprzedzających ich powstanie można łatwo wykazać, że chrztu nie zawsze udzielali święci szafarze. To stało się jeszcze bardziej oczywiste wtedy, gdy wśród donatystów najpierw nastąpiły podziały, a potem ponowne zjednoczenie $^{31}$. Wtedy to, wbrew głoszonym przez siebie zasadom, donatyści nie powtarzali chrztu udzielonego w formalnej schizmie. Augustyn trzeźwo i nieco z przekąsem zauważył ten fakt, ale też wyciągnął z niego stosowne wnioski. Najważniejszy z nich dotyczył ważności chrztu. Przyjmowanie bez ponawiania chrztu osób ochrzczonych w schizmie przeczyło zasadzie uzależnienia ważności chrztu od łączności szafarza z „Kościołem świętych”.

Jednak ścisły związek zachodzący między chrztem i Kościołem nie ulegał dla Augustyna najmniejszej wątpliwości. W jego przekonaniu, wszystkie dobra

27 Augustyn powoływał się na słowa Cypriana o niegodnych członkach Kościoła, por. De baptismo IV 13, 20; V 18, 24.

28 Tamże VI 3, 5, CSEL 51, 301, ŹMT 38, 166.

29 Tamże VI 2, 3, CSEL 51, 300, ŹMT 38, 165.

30 Por. tamze IV 10, 16.

31 Chodzi o tzw. schizmę Maksymiliana, por. Żurek, Wstęp, s. 10. 
związane z chrztem otrzymuje się poprzez Kościół i tylko ten, kto w pełni należy do Kościoła, może zyskać owoce tego sakramentu. Jednakowoż sam sakrament - podobnie jak inne dobra duchowe Kościoła - może znaleźć się poza nim i być tam bezprawnie używane ${ }^{32}$. Tylko, że poza Kościołem dobra te stają się bezużyteczne. $\mathrm{Z}$ tego też powodu:

„Nie należy negować sakramentu chrztu, chociażby został on przyjęty poza Kościołem. Nie zapewnia on jednak zbawienia, o ile ten, który posiada pełnię chrztu, poprawiwszy się ze swoich nieprawości, nie zostanie włączony do Kościoła”33.

Zgodnie z tym nie sposób negować istnienia sakramentu chrztu również u donatystów. Mówiąc obrazowo:

„Kościół rodzi wszystkich przez chrzest. Bądź to w sobie, czyli ze swego łona, bądź. też na zewnątrz, $\mathrm{z}$,nasienia swego męża” ${ }^{34}$.

Jednak: „Cokolwiek posiada się z Kościoła, to poza nim nie służy ku zbawieniu" 35 . W przypadku omawianego tu sakramentu:

„,chrzest zaczyna mieć wpływ na odpuszczenie grzechów, w chwili, gdy przyjdą do pokoju Kościoła"36.

Przedstawione tu w zarysie zasady odnoszą się w pierwszym rzędzie do tych wszystkich, którzy w sposób widzialny i formalny zerwali więź z Kościołem, a więc schizmatycy i heretycy. Nie sposób jednak zapomnieć o tych, którzy wprawdzie formalnie należą do Kościoła, choć w rzeczywistości są poza nim. Za takich uważał Augustyn wszystkich: „żyjących wbrew Chrystusowi, czyli postępują wbrew Jego przykazaniom"37. Byli wśród nich szafarze, ale też przyjmujący chrzest, bez rzeczywistego nawrócenia. Dla nich chrzest pozostawał bezowocny, aż do chwili szczerego nawrócenia. Do nich wszystkich należy odnieść generalną zasadę:

„Integralność sakramentu jest uznana wszędzie, ale poza jednością Kościoła nie wystarczy ona do nieodwołalnego odpuszczenia grzechów"38.

Nie wystarczy zatem być prawdziwie ochrzczonym, by dostąpić skutków tego sakramentu. Konieczna jest łączność z Kościołem, a ta zgodnie z wizją Kościoła reprezentowaną przez Augustyna nie sprowadza się do czysto formal-

${ }^{32} \mathrm{~W}$ opinii Augustyna można mówić o prawnym (recte) i nieprawnym (illicite) korzystaniu z dóbr duchowych Kościoła, por. De baptismo I 34.

33 Tamże IV 21, 28, CSEL 51, 256, ŹMT 38, 127.

34 Tamże I 15, 23, CSEL 51, 167, ŹMT 38, 51.

${ }^{35}$ Tamże IV 18, 25, CSEL 51, 252, ŹMT 38, 123.

${ }^{36}$ Tamże III 13, 18, CSEL 51, 208, ŹMT 38, 85.

37 Tamże IV 3, 4, CSEL 51, 224-225, ŹMT 38, 100.

38 Tamże III 17, 22, CSEL 51, 214, ŹMT 38, 91. 
nej przynależności ${ }^{39}$. Zapewnia ją przede wszystkim wewnętrzna dyspozycja przystępującego do chrztu. Jest ona na tyle istotna, że umożliwia przyjęcie waże i owocne chrztu nawet we wspólnocie schizmatyckiej, o ile zmusza do tego konieczność (np. niebezpieczeństwo śmierci).

3. Nawrócenie serca. Przyjęcie chrztu wcale nie oznacza, że zawsze jest on człowiekowi pomocny. Od samego bowiem sakramentu należy odróżnić jego efekt $^{40}$. Mówiąc o chrzcie Augustyn: „wprowadza znaczące rozróżnienie. $\mathrm{Z}$ jednej strony to Chrystus działa w sakramentach, to On sprawia, że sakrament istnieje. Jest zatem w sakramencie pewna fundamentalna rzeczywistość [...]. Z drugiej strony sakrament nie zawsze odnosi swój zbawczy skutek"41. W istocie rzeczy nie zawsze „święty chrzest” przynosi swoje owoce temu, który został nim ochrzczony. Augustyn za najważniejszy skutek chrztu uznawał odpuszczenie grzechów, lub ujmując to w sposób bardziej generalny - „odrodzenie z Ducha i wody" 42 . Przyznawał jednak i mocno to podkreślał, że nie każdy ochrzczony tak się „odradza” i dostępuje odpuszczenia grzechów ${ }^{43}$. Co więcej, dar chrztu, źle wykorzystany, może obciążać człowieka przed Bogiem. Możliwe jest, że ,przez ten sam chrzest dobrzy katolicy zostają zbawieni, a źli katolicy lub heretycy są potępieni” ${ }^{44}$, bo chrzest służyć może także „ku zgubie, jak wielki dar Boży, źle wykorzystywany"45.

Nie w każdym zatem człowieku sakrament chrztu działa. Zbawczych jego skutków nie dostępują przede wszystkim ci, którzy w sposób świadomy i dobrowolny decydują się na przyjęcie tego sakramentu poza Kościołem katolickim, albo też w tym Kościele, ale bez właściwej dyspozycji ducha, czyli bez prawdziwego nawrócenia, co w języku Augustyna nazwane było „nawróceniem serca" (conversio cordis).

Zgodnie z praktyką ówczesnego Kościoła chrztu udzielano osobom dorosłym, po stosownym przygotowaniu. Istotnym elementem chrztu było wyznanie wiary i złożenie przyrzeczeń chrzcielnych. Ten właśnie akt miał, zdaniem Augustyna, istotne znaczenie dla dostąpienia owoców tego sakramentu. Lapidarnie wyraził to w zdaniu:

„o ile do chrztu przystępują z prawdziwym nawróceniem serca, otrzymują życie od Tego, do którego należy chrzest. Jeżeli natomiast wyrzekają się świata tylko

${ }^{39}$ Na temat augustyńskiej koncepcji Kościoła por. J. Ratzinger, Popolo e casa di Dio in sant'Agostino, Milano $2005^{2}$.

${ }^{40}$ Por. Augustinus, De baptismo VI 1, 1, CSEL 51, 298: „ab effectu”.

${ }^{41}$ H. Bourgeois, Świadectwo dawnego Kościoła: ekonomia sakramentalna, w: Znaki zbawienia, red. H. Bourgeois - B. Sesboüé - P. Tihon, tłum. P. Rak, Kraków 2001, 37.

42 Augustinus, De baptismo VI 12, 19, CSEL 51, 310, ŹMT 38, 173.

43 Por. tamże III 13, 18.

44 Tamże V 28, 39, CSEL 51, 297, ŹMT 38, 162.

45 Tamże V 22, 30, CSEL 51, 288, ŹMT 38, 154. 
werbalnie, ale nie w praktyce [...] to o ile się nie nawrócą, nie zostaną ożywieni, jakkolwiek mają prawdziwy chrzest" ${ }^{, 46}$.

Taki bowiem człowiek ,nie dopuszcza, aby zostały mu odpuszczone grzechy, bo sercem swoim uporczywie trwa przy złości i bezbożności”47. Szczerość w składaniu przyrzeczeń umożliwia objawieniu się mocy sakramentu chrztu, bowiem ,dzięki świętości chrztu dokonuje się odpuszczenie win”48. W przypadku braku prawdziwego nawrócenia sakrament chrztu działa dopiero wówczas, gdy ochrzczony szczerze zaczyna realizować złożone przyrzeczenia. Wówczas dopiero „sakrament stanowiący wcześniej powód do zguby dla tych, którzy się nie przemieniają, zaczyna teraz w przemienionych działać ku ich zbawieniu"49.

Od obłudy tych, którzy tylko pozornie składają przyrzeczenia chrzcielne należało odróżnić ludzi deklarujących przy chrzcie wiarę w Boga, a w istocie błędnie rozumiejących te prawdy wiary.

„Gdy chodzi o samą integralność i świętość sakramentu, to nie ma znaczenia, w co wierzy i jaką wiarą napełniony jest ten, kto przyjmuje sakrament" $"$.

Zapewne opierając się na duszpasterskim doświadczeniu Augustyn pisał:

„Może się zdarzyć, że człowiek będzie miał integralny sakrament, ale przewrotną wiarę. Podobnie jak może się zdarzyć, że zna dokładnie słowa Symbolu, a jednak wierzy nie w sposób należyty, czy to w odniesieniu do kwestii samej Trójcy, czy zbawienia, czy w jakiejkolwiek innej" ${ }^{\prime 1}$.

Odwołując się do terminologii św. Pawła, nazwie takich ludzi „,zmysłowymi” (1Kor 1, 13), myślącymi w sposób cielesny i rozumiejących „prawdy o Bogu zgodnie ze zmysłowym charakterem swojego ciała" 52 . Błąd może być wprawdzie niezawiniony, ale obiektywnie rzecz biorąc ochrzczony - zdaniem Augustyna - pozostaje heretykiem. Chociaż „posiada chrzest”, to zbawienne jego skutki dotkną go wówczas, gdy „przylgnąwszy do wiary katolickiej wyrzuca z duszy wcześniejszy błąd" 53 .

4. Konieczność chrztu. W kontekście sporu o ważność i skuteczność chrztu, pojawiła się kwestia jego użyteczności i konieczności przyjęcia. Jak można wnioskować z wypowiedzi Augustyna, duszpasterzy zaniepokoić mogły dwa zjawiska

\footnotetext{
46 Tamże V 18, 24, CSEL 51, 283, ŹMT 38, 150.

47 Tamże I 12, 18, CSEL 51, 163, ŹMT 38, 47.

48 Tamże III 13, 18, CSEL 51, 208, ŹMT 38, 85.

49 Tamże IV 3, 4, CSEL 51, 224, ŹMT 38, 99

50 Tamże III 14, 19, CSEL 51, 208, ŹMT 38, 86.

51 Tamże.

52 Tamże.

53 Tamże III 14, 19, CSEL 51, 210, ŹMT 38, 87.
} 
dotyczące podejścia do chrztu, które wymagały z ich strony reakcji. Duszpasterzy, na czele z Augustynem, niepokoił fakt, że pojawili się ludzie, którzy przystępowali do chrztu w sekcie Donata, uzasadniając swoją decyzję nie tyle przekonaniem do nauki tam głoszonej, ile powołując się na stanowisko także Kościoła katolickiego, według którego chrzest udzielony przez donatystów należy uznać za ważny. Skoro tak, to - jak argumentowali - nie ma różnicy gdzie się go przyjmie. Za wyborem akurat donatystów przemawiać mogły względy personalne lub też czysto praktyczne. Taką postawę i ten typ argumentacji, Augustyn korygował nauką o skuteczności chrztu w Kościele, o czym było wyżej.

Pojawiali się również tacy, którzy dostrzegając przeciętność moralną wielu katolików, nie widzieli potrzeby przyjmowania sakramentu chrztu. Tacy ludzie:

„rozumieniem prawdy i godnymi pochwały obyczajami doszli do takiej doskonałości, że nie mają najmniejszej wątpliwości, by uważać się za lepszych od wielu ochrzczonych, ze względu na sposób życia i wiedzę. Żyją w przekonaniu, że dla nich zbyteczną rzeczą będzie przyjmowanie chrztu, gdyż w swoim mniemaniu osiągnęli taki stan ducha, do jakiego usiłuje dopiero dojść wielu ochrzczonych" ${ }^{\text {. }}$.

Augustyn nie kwestionował, że ludzie mogą bez chrztu osiągnąć duży stopień doskonałości moralnej, cieszyć się łaskawością Boga, a nawet być narzędziem Ducha Świętego. Taki stan jest możliwy i nawet są na to biblijne dowody. Koronnym przykładem dla Augustyna był Korneliusz z Dziejów Apostolskich. Nikt nie mógł mu odmówić chrześcijańskiej postawy, którą zasłużył sobie na łaskawość Boga.

\begin{abstract}
„Nie wolno nam negować sprawiedliwości, jaką posiadł człowiek, zanim jeszcze włączony został do Kościoła. Tak przecież zaczęła się sprawiedliwość Korneliusza, wpierw nim przynależał on do ludu chrześcijańskiego. Aby nie została ona zanegowana, anioł powiedział do niego: «Jałmużny twoje zostały przyjęte, modlitwy twoje wysłuchane» (Dz 10,4.31). Ale gdyby to wystarczyło do otrzymania królestwa niebieskiego, nie zostałby upomniany, by posłać po Piotra" ${ }^{55}$.
\end{abstract}

Chrześcijańska postawa w życiu i świadectwo dobrych czynów decydowały o tym, że „lepszym był setnik Korneliusz jeszcze nie ochrzczony od Szymona już ochrzczonego" 56 . Podobnie może się zdarzyć, przyznawał Augustyn, w sytuacji np. katechumena i człowieka już ochrzczonego. Jednak to nie wystarcza do zbawienia, bo zgodnie ze świadectwami Pisma Świętego:

„By sama sprawiedliwość katechumena nie [wydawała] się wystarczającym zabezpieczeniem, zostało powiedziane: «Jeżeli się ktoś nie odrodzi z wody i Ducha, nie wejdzie do królestwa niebieskiego» (J 3, 5)"57.

\footnotetext{
${ }^{54}$ Tamże IV 22, 29, CSEL 51, 258, ŹMT 38, 128.

55 Tamże IV 21, 28, CSEL 51, 256, ŹMT 38, 126.

56 Tamże IV 21, 28, CSEL 51, 255, ŹMT 38, 126.

57 Tamże IV 21, 28, CSEL 51, 256, ŹMT 38, 126.
} 
Powyżej przypomniane słowa Chrystusa były dla Augustyna wystarczającym i niepodważalnym argumentem uzasadniającym konieczność chrztu. Stanowczo twierdził:

„,nikomu nie wolno gardzić sakramentem, wprawdzie udzielanym w sposób fizyczny przez działanie szafarzy, ale przez który Bóg dokonuje konsekracji człowieka w sposób duchowy. Nawet gdyby ktoś już przed chrztem w rozwoju wewnętrznego człowieka doszedł pobożnym sercem do duchowego rozumienia" ${ }^{\text {" }}$.

Tego, co dokonuje się w czasie chrztu nic nie może zastąpić. Dzieje się tak z woli Bożej i trzeba z tym się pogodzić. W przekonaniu Augustyna przekonują o tym nie tylko wyżej cytowane słowa Chrystusa, ale też Jego przykład. Do takiego wniosku ma prowadzić przyjęcie przez Chrystusa chrztu Jana. Zdaniem Augustyna:

,Janowi obowiązek udzielania chrztu [...] został powierzony tylko dlatego, by sam Pan, który ten obowiązek zlecił, przez to, że nie wzgardził chrztem sługi, wskazał drogę pokory" ${ }^{\circ 9}$.

Jednocześnie jednak przyznaje się do trudności zrozumienia w pełni wydarzenia w Jordanie. „Gdyby to jednak było bez znaczenia, to Pan nie przyjąłby chrztu sługi" ${ }^{60}$.

Chrzest jawi się zatem jako nieodzowny warunek zbawienia. Jednakże sam Chrystus obiecał raj łotrowi na krzyżu, choć nie było warunków na udzielenie mu chrztu. Co więcej, sam łotr „nie został ukrzyżowany za imię Chrystusa, ale w zapłatę za swoje występki”" ${ }^{61}$. Nie było to wcale męczeństwo za wiarę. Co więc zastąpiło chrzest? Augustyn znalazł takie wyjaśnienie:

„dochodzę do wniosku, że nie tylko męczeństwo dla imienia Chrystusa może zrekompensować brak chrztu, ale także wiara i nawrócenie serca, o ile na celebrowanie misterium chrztu nie pozwala brak czasu [...], gdy posługę chrztu wyklucza nie pogarda religii, ale okoliczności”, ${ }^{\prime 2}$.

Zbawienie dokonujące się w ten sposób znajduje uzasadnienie w słowach św. Pawła: ,sercem przyjęta wiara prowadzi do usprawiedliwienia, wyznana ustami - do zbawienia” ( $\mathrm{Rz} 10,10)$. Dzięki wierze łotra jego „zbawienie było pełne” a ,fizyczny element sakramentu był w nim duchowo obecny"63. W ten sposób została sformułowana dość szeroka zasada, w oparciu o którą można myśleć o zbawieniu wielu znajdujących się poza oddziaływaniem chrztu udzielanego przez Kościół.

\footnotetext{
58 Tamże IV 21, 28, CSEL 51, 256, ŹMT 38, 127.

59 Tamże IV 21, 28, CSEL 51, 257, ŹMT 38, 127.

60 Tamże, CSEL 51, 258, ŹMT 38, 128.

61 Tamże IV 22, 29, CSEL 51, 257, ŹMT 38, 127.

62 Tamże.

63 Tamże IV 23, 30, CSEL 51, 258, ŹMT 38, 128.
} 
Wprawdzie oprócz traktatu $O$ chrzcie ukazało się jeszcze kilka antydonatystycznych pism Augustyna, ale dla kwestii chrztu ten jest najbardziej reprezentatywny ${ }^{64}$. W tym traktacie zawarł Augustyn istotne elementy swojej teologii chrztu. Kilka z nich zasługuje na szczególne zauważenie. W przemyśleniach Augustyna uderza zwrócenie uwagi na chrystocentryczny wymiar sakramentu chrztu. Chrystus jest ukazany nie tylko jako twórca sakramentu, ale przede wszystkim jako ten, który poprzez chrzest działa. Rola szafarza, tak eksponowana przez poprzedników Augustyna i jego adwersarzy, przestała być znacząca.

Inaczej też ujął Augustyn eklezjalny wymiar sakramentu chrztu. Wynikało to z jego odmiennej wizji Kościoła. Nie podzielał ,,jurydycznej” wizji Kościoła, jaką miał Cyprian ${ }^{65}$, ani też jak dla Orygenesa Kościół nie był „rzeczywistością obejmującą wszystko i wszystkich"66. O przynależności do Kościoła decyduje, zdaniem Augustyna, miłość (caritas) rozlana w sercach ( $\mathrm{Rz} 5,5)$. W konsekwencji, to nie formalna przynależność do Kościoła jest gwarantem posiadania łaski i zyskania odpuszczenia grzechów, ale wewnętrzna więź z Bogiem.

Nowatorskie też okazało się rozróżnienie w sakramencie chrztu tego, co późniejsza teologia nazwie ważnością chrztu od jego owocności. Według Augustyna, samo udzielenie sakramentu nie oznacza jego działania ${ }^{67}$. Nowe i pogłębione spojrzenie na sakrament chrztu było nie tylko skuteczne w polemice z donatystami. Jak się później okazało, Augustyn wyznaczył kierunek myślenia, który zyskał uznanie w całym Kościele łacińskim.

\title{
IL BATTESIMO E LA SALVEZZA DELL'UOMO: \\ LA VALIDITÀ E LA NECESSITÀ DEL BATTESIMO NELLA LUCE DELLA POLEMICA DI AGOSTINO CON I DONATISTI
}

\author{
(Riassunto)
}

Uno dei più grandi temi che Agostino discussi con i donatisti fu il tema del battesimo. I donatisti difendevano la loro pratica di ribattezzare quelli che passa-

${ }^{64} \mathrm{Na}$ temat innych pism antydonatystycznych por. Żurek, Wstęp, s. 13.

${ }^{65}$ Szerzej por. J. Ratzinger, Popolo e casa di Dio, s. 99nn.

${ }^{66}$ Pietras, Dionizy Aleksandryjski wobec sporu, s. 110.

${ }^{67}$ Por. In Iohannis evangelium tractatus 26, 11, CCL 36, 265: „aliud est sacramentum, aliud virtus sacramenti". 
vano nella loro file fondandosi sull'autorità di Cipriano. Dal loro punto di vista solo la „Chiesa dei santi” ha il potere di battezzare. Secondo Agostino occorre distinguere il sacramento in se stesso, che è sempre Santo, perché è di Christo, dagli effetti del Sacramento, che sono la remissione dei peccati e il dono dello Spirito Santo. Questi effetti non si verificano se non c'è una vera conversione del cuore e se non si vive nella „,communio sanctorum” che è la Chiesa. Nell'articolo viene sviluppato la dimensione cristologica ed ecclesiale del sacramento del battesimo secondo Agostino. 